\title{
Low-dose Streptozotocin-Induced Autoimmune Diabetes is Under the Genetic Control of the Major Histocompatibility Complex in Mice
}

\author{
U. Kiesel and H. Kolb \\ Diabetes Research Institute, University of Düsseldorf, Düsseldorf, FRG
}

\begin{abstract}
Summary. In mice, an experimental autoimmune diabetes can be induced by multiple injections with low doses of streptozotocin. Since different mouse strains show a varying susceptibility towards this treatment, we have examined whether the experimental autoimmune diabetes is under the genetic control of the major histocompatibility complex (H-2 complex). Mice of five congenic resistant strains, differing in their genome only at the $\mathrm{H}-2$ region, were identically treated on five consecutive days with $40 \mathrm{mg}$ streptozotocin $/ \mathrm{kg}$ body weight. Genes at the $\mathrm{H}-2$ complex were found to determine the susceptibility towards the diabetogenic effect of streptozotocin: mice of $\mathrm{H}-2$ haplotype $\mathrm{k}$ (B10.BR) developed persistent and strong hyper-
\end{abstract}

glycaemia (blood glucose approximately $17 \mathrm{mmol} / \mathrm{l}$ ), mice of strain B10.A (H-2a), C57BL/10 (H-2 $)$ and B10.D2 (H-2 $)$ reacted with moderate hyperglycaemia (between 11.5 and $15.5 \mathrm{mmol} / \mathrm{l})$, whereas mice of strain B10.S $\left(\mathrm{H}-2^{\mathrm{s}}\right)$ were resistant to the diabetogenic effect of low-dose streptozotocin except for a small and transient rise of blood glucose levels. It is concluded that genes within the major histocompatibility complex affect the diabetogenic response to multiple low-dose streptozotocin treatment.

Key words: H-2 dependence, experimental autoimmune diabetes, streptozotocin, genetic control, mice.
Streptozotocin, when given on consecutive days in subdiabetogenic doses, induces in susceptible mice a progressive loss of B islet cell function leading to hyperglycaemia $[1,2]$. The low-dose streptozotocin-induced diabetes has been taken as a model of human Type I (insulin-dependent) diabetes. In both cases lymphocytic infiltration (insulitis) was observed during the early phases of the disease. An impact of viral and immune factors in the pathogenesis has been postulated [3-5]. Mice can be protected from the disease by immunosuppressive treatment [6]. Low-dose streptozotocin-induced insulitis has been transferred into healthy mice by means of lymphocytes from diabetogenic animals [7]. Whether recipient mice develop hyperglycaemia is still a matter of dispute [7-10]. As in the human disease, genetic factors seem to be involved in the animal model, i.e. inbred mouse strains differ widely in their susceptibility towards the diabetogenic effect of streptozotocin [11, 12]. In addition, we have shown that the successful transfer of insulitis by lymphocytes depends on a permissive genetic background [13]. This study was designed to investigate whether genes within the major histocompatibility complex (H-2 complex) in mice affect the low-dose streptozotocin-induced diabetes.

\section{Materials and Methods}

Male mice of the following five congenic resistant strains: B10.A/0la $\left(\mathrm{H}-2^{\mathrm{a}}\right), \mathrm{C} 57 \mathrm{BL} / 10 \mathrm{ScSn} / 0 \mathrm{la}\left(\mathrm{H}-2^{\mathrm{b}}\right), \mathrm{B} 10 . \mathrm{D} 2 / \mathrm{n} / 01 \mathrm{la}\left(\mathrm{H}-2^{\mathrm{d}}\right), \mathrm{B} 10 . \mathrm{BR} / 01 \mathrm{a}$ $\left(\mathrm{H}-2^{k}\right)$ and B10.S/0la $\left(\mathrm{H}-2^{5}\right)$, aged 8-10 weeks, were obtained from OLAC 1976 Ltd, Shaw's Farm, Bicester Oxon, UK. The experimental animals received five doses of streptozotocin $(40 \mathrm{mg} / \mathrm{kg}$ body weight, Boehringer, Mannheim, FRG) on consecutive days. The compound was injected IP immediately after solution in sodium citrate $(0.025 \mathrm{~mol} / \mathrm{l}, \mathrm{pH} 4.0)$, using $0.5 \mathrm{ml}$ per animal. In each strain, $13-26$ animals were injected with streptozotocin and 6-12 control mice received injections of buffer alone. All mice were kept on the same standard $\operatorname{diet}$ ('ssniff M', Ssniff, Soest, FRG).

Blood of non-fasted mice was drawn from the retro-orbital vein plexus between 0900 and $1100 \mathrm{~h}$. Blood was sampled before starting the experiments and on days 21,50 and 100 and determined in a Technicon autoanalyzer using the hexokinase method of Boehringer.

All data are expressed as mean \pm SEM. Statistical significance of differences were determined by Student's t-test for independent samples (two-tailed).

\section{Results}

The response of the five congenic mouse strains is compared in Table 1 and Figure 1. Mice of strain B10.BR $\left(\mathrm{H}-2^{\mathrm{k}}\right)$ responded to low-dose streptozotocin treatment 
Table 1. Corresponding alleles of the $\mathrm{H}-2$ subregions of congenic resistant mouse strains and their response to treatment with streptozotocin

\begin{tabular}{lllllllllll}
\hline & K & A & B & J & E & C & S & G & D & $\begin{array}{l}\text { Response to } \\
\text { streptozotocin }\end{array}$ \\
\hline B10.BR & k & k & k & k & k & k & k & k & k & high \\
\hline B10.A & k & k & k & k & k $/$ & d & d & d & d & moderate \\
B10.D2 & d & d & d & d & d & d & d & d & d & moderate \\
C57BL $/ 10$ & b & b & b & b & b & b & b & b & b & moderate \\
\hline B10.S & s & s & s & s & s & s & s & s & s & low
\end{tabular}

The position where crossing-over occurred in the recombinant B10.A strain is indicated by $(/)$

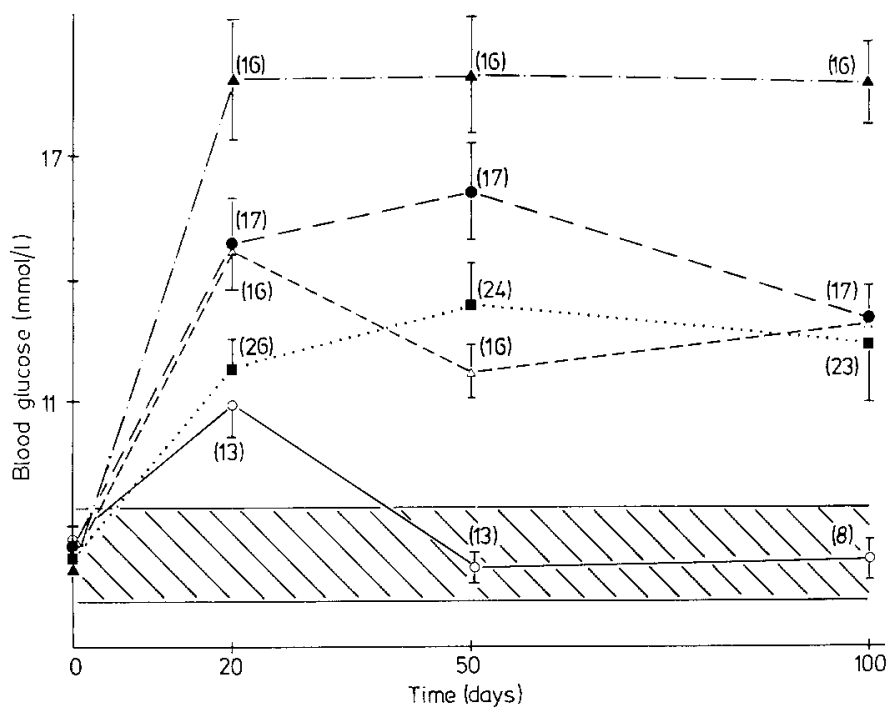

Fig. 1. H-2 dependence of experimental autoimmune diabetes in congenic resistant mouse strains as demonstrated by the development of blood glucose concentrations after treatment with streptozotocin (40 $\mathrm{mg} / \mathrm{kg}$ body weight) daily for 5 days. Mean values \pm SEM are shown with the relevant numbers of mice in parantheses. $\mathbf{A} \cdot \cdot \cdot \cdot . . \Delta$ $=\mathrm{B} 10 . \mathrm{BR}\left(\mathrm{H}-2^{\mathrm{k}}\right) ;-\cdots-\mathbf{C}=\mathrm{C} 57 \mathrm{BL} / 10\left(\mathrm{H}-2^{\mathrm{b}}\right) ; \Delta-\cdots--\Delta=$ B10.A $\left(H-2^{\mathrm{a}}\right) ; \mathbf{\square} \cdots \cdots=\mathrm{B} 10 . \mathrm{D} 2\left(\mathrm{H}-2^{\mathrm{d}}\right) ; \mathrm{O}-\mathrm{O}=$ B10.S $\left(H-2^{5}\right)$. Hatched area $=$ range of mean blood glucose values of buffer treated control animals of all five mouse strains

with persistent hyperglycaemia (mean blood glucose values approximately $17 \mathrm{mmol} / \mathrm{l})$. Mice of strain C57BL/10 (H-2 $\left.2^{b}\right)$ B10.A (H-2 $\left.{ }^{a}\right)$ and B10.D2 (H-2d $)$ responded with moderate hyperglycaemia (mean blood glucose concentrations of 11.5 and $15.5 \mathrm{mmol} / \mathrm{l}$ on days 21 and 50 falling to $12 \mathrm{mmol} / \mathrm{l}$ on day 100 after streptozotocin treatment). Most of these values were significantly different from those of strain B10.BR $(2 p<0.05$ or 0.01 , respectively). The lowest blood glucose concentrations following streptozotocin injections were seen in mice of strain B10.S $\left(\mathrm{H}-2^{\mathrm{s}}\right)$. After an initial rise to $11 \mathrm{mmol} / \mathrm{l}$, mean blood glucose concentrations fell to approximately $8 \mathrm{mmol} / \mathrm{l}$, which was significantly different from the results seen in the other four strains $(2 p<0.01)$. Also included in Figure 1 is the area of normoglycaemic values of buffer-treated control animals of all five congenic resistant strains.
The body weight was determined regularly in all experimental animals and no major loss was observed. A few apparently sick animals were seen only in strain B10.D2 and these were eliminated from the study in order not to bias average blood glucose levels.

\section{Discussion}

In the experiments presented here an attempt has been made to determine whether genes within the major histocompatibility complex control low-dose streptozotocin-induced diabetes in mice. The comparison of five strains differing only at their $\mathrm{H}-2$ region shows significant differences in the susceptibility towards the diabetogenic action of low-dose streptozotocin. Mice of strain B10.BR $\left(\mathrm{H}-2^{\mathrm{k}}\right)$ responded with strong and persistent hyperglycaemia and mice of strains $\mathrm{C} 57 \mathrm{BL} / 10\left(\mathrm{H}-2^{\mathrm{b}}\right)$, B10.A $\left(\mathrm{H}-2^{a}\right)$ and B10.D2 $\left(\mathrm{H}-2^{\mathrm{d}}\right)$ had significantly lower mean blood glucose levels during the observation period of 100 days. Mice of strain B10.S (H-2 $)$ did not develop hyperglycaemia except for a transient and moderate increase of blood glucose values.

These data indicate that genes located at the $\mathrm{H}-2$ region of mice affect the diabetic response to low-dose streptozotocin treatment. Different haplotypes of $\mathrm{H}-2$ determine a state of high susceptibility $\left(\mathrm{H}-2^{\mathrm{k}}\right)$ or a state of resistance $\left(\mathrm{H}-2^{\mathrm{s}}\right)$. It is of interest that strain DBA $/ 2$, carrying the $\mathrm{H}-2^{\mathrm{d}}$ gene complex on a different genetic background, has turned out to be highly susceptible to lowdose streptozotocin treatment [14]. This observation suggests that genes outside the $\mathrm{H}-2$ region are also involved in the genetic control of this disease. A major influence of non-H-2 genes has been concluded from the comparison of several mouse strains with similar $\mathrm{H}-2$ regions [11].

The susceptibility of mice to the diabetogenic action of low-dose streptozotocin thus appears to be controlled by at least two genes, one within and one outside the major histocompatibility complex. Our results do not allow any conclusion on the mode of action of $\mathrm{H}-2$ genes. Resistance or susceptibility to low-dose streptozotocin may be determined on the level of streptozotocin - B cell interactions, B cell regeneration and/or immunological B cell destruction. We have recently presented evidence that resistance to low-dose streptozotocin treatment is controlled at the level of immunoregulation in mouse strain BALB/c $\left(\mathrm{H}-2^{\mathrm{d}}\right)$ [12]. Mice of this strain become susceptible to the diabetogenic effect of low-dose streptozotocin after application of low doses of cyclophosphamide. Such a treatment is known to inactivate T-suppressor cells preferentially [15]. Experiments to determine the mechanism of $\mathrm{H}-2$ gene control of low-dose streptozotocin-induced diabetes are in progress.

Our observations relate to findings in other animal models of human Type I diabetes. In the diabetes of mice induced by the M-variant of EMC virus, an influence of either non-H-2 genes [16, 17] and $\mathrm{H}-2$ genes [18] was 
found, whereas the induction of glucose intolerance after immunization with pancreatic antigens seems to be only $\mathrm{H}-2$ controlled [18].

Acknowledgements. We thank Mrs. R.Heller, M.Soumagne and L. Uebber for excellent technical assistance and Professor Dr. F.A.Gries for critical reading of the manuscript. This work was supported by the Deutsche Forschungsgemeinschaft, Sonderforschungsbereich 113 'Diabetesforschung Düsseldorf' and the Minister für Wissenschaft und Forschung des Landes Nordrhein-Westfalen, FRG.

\section{References}

1. Like AA, Rossini AA (1976) Streptozotocin-induced pancreatic insulitis: new model of diabetes mellitus. Science 193: 415-417

2. Like AA, Rossini AA (1978) Streptozotocin-induced pancreatic insulitis in mice. Morphological and physiological studies. Lab Invest $38: 470-486$

3. Craighead JE (1978) Current views on the etiology of insulin-dependent diabetes mellitus. N Engl J Med 299:1439-1445

4. Notkins AL (1977) Virus-induced diabetes mellitus. Arch Virol 54: $1-17$

5. Cahill FC, McDevitt HO (1981) Insulin-dependent diabetes mellitus: the initial lesion. N Engl J Med 304: 1454-1465

6. Rossini AA, Williams RM, Appel MC, Like AA (1978) Complete protection from low-dose streptozotocin-induced diabetes in mice. Nature 276: 182-184

7. Kiesel U, Freytag G, Biener J, Kolb H (1980) Transfer of experimental autoimmune insulitis by spleen cells in mice. Diabetologia 19: $516-520$

8. Buschard K, Rygaard J (1977) Passive transfer of streptozotocin-induced diabetes mellitus with spleen cells. Acta path microbiol scand (Sect C) 85:469-472

9. Beattie G, Lannom R, Lipsick J, Kaplan NO, Osler AG (1980) Streptozotocin-induced diabetes in athymic and conventional $\mathrm{BALB} / \mathrm{c}$ mice. Diabetes 29: 146-150
10. Paik SG, Fleischer N, Shin SI (1980) Insulin-dependent diabetes mellitus induced by subdiabetogenic doses of streptozotocin: $\mathrm{Ob}-$ ligatory role of cell-mediated autoimmune processes. Proc Nat Acad Sci USA 77: 6129-6133

11. Rossini AA, Appel MC, Williams RM, Like AA (1977) Genetic influence of the streptozotocin-induced insulitis and hyperglycemia. Diabetes 26:916-920

12. Kiesel U, Greulich B, Marx-Soho Moumé C, Kolb H (1981) Induction of experimental autoimmune diabetes by low-dose streptozotocin treatment in genetically resistant mice. Immunol Letters 3: $227-230$

13. Kiesel U, Kolb H, Freytag G (1981) Strain dependency of the transfer of experimental immune insulitis in mice. Clin Exp Immunol $43: 430-433$

14. Kolb H, Kiesel U (1981) Localization of genes controlling an experimental model of human insulin-dependent diabetes mellitus within and outside the major histocompatibility complex. Immunobiol 160: 58-59 (Abstract)

15. Shand FL, Liew FY (1980) Differential sensitivity to cyclophosphamide of helper T cells for humoral responses and suppressor T cells for delayed-type hypersensitivity. Eur J Immunol 10:480-483

16. Boucher DW, Hayashi K, Rosenthal J, Notkins AL(1975) Virus-induced diabetes mellitus. III. Influence of the sex and the strain of the host. J Infect Dis 131: 462-466

17. Yoon JW, Lesniak MA, Fussganger R, Notkins AL (1976) Genetic differences in susceptibility of pancreatic $\beta$ cells to virus-induced diabetes mellitus. Nature 264: 178-180

18. Kromann H, Lernmark A, Yestergaard BF, Egeberg J, Nerup J (1979) The influence of the major histocompatibility complex (H-2) on experimental diabetes in mice. Diabetologia 16:107-114

Received: 28 July 1981

and in revised form: 22 February 1982

Dipl.-Biol. Ulrich Kiesel

Diabetes-Forschungsinstitut an der Universität Düsseldorf

Auf'm Hennekamp 65

D-4000 Düsseldorf, FRG 